ANITA STEFAŃSKA

ORCID 0000-0002-6414-6151

Uniwersytet im. Adama Mickiewicza

$w$ Poznaniu

\title{
JA PRZEZ TEATR \\ CZYLI O TEATRZE TERAPEUTYCZNYM \\ DOROSŁYCH AKTORÓW \\ Z NIEPEŁNOSPRAWNOŚCIĄ INTELEKTUALNĄ \\ I O PEWNOŚCI SIEBIE W DZIAŁANIU
}

\begin{abstract}
Stefańska Anita, Ja przez teatr, czyli o teatrze terapeutycznym dorostych aktorów z niepetnosprawnościa intelektualna i o pewności siebie w działaniu [Me Through the Theater, or About the Therapeutic Theater of Adult Actors with Intellectual Disability and One's Confidence in Action]. Studia Edukacyjne nr 57, 2020, Poznań 2020, pp. 77-88. Adam Mickiewicz University Press. ISSN 1233-6688. DOI: $10.14746 /$ se.2020.57.6

Support for stage creativity and acting in theater therapy is to encourage participants, i.e. adults with intellectual disabilities, not so much to demonstrate theatrical skills and aesthetic sensitivity, but to discover something new in themselves, important for health and psychosocial well-being. In the therapeutic theater, building a spectacle involves overcoming personal limitations and challenging oneself. The potential benefit of this process may be gaining confidence, an important state in the area of social relations. The article aims to indicate the conditions for raising the level of self-confidence of adults with intellectual disabilities who participate in theater therapy and to indicate the consequences harmful for interpersonal relationships, while self-confidence is associated with more negative attitudes towards other people.
\end{abstract}

Key words: actor - adult with intellectual disability, therapeutic theater, support, self-confidence

\section{Wprowadzenie}

Zaobserwowano już dawno, że gra teatralna (drama) dostarcza aktorom z niepełnosprawnością intelektualną radosnych doznań oraz zapewnia rozwój określonych kompetencji. Te ostatnie mogą następnie przyczyniać się do osiągania korzyści osobistych, takich jak podnoszenie pewności siebie, zwiększenie samooceny, czy rozwijanie ogólnych umiejętności. Korzyści spo- 
łeczne z osiągnięcia większej pewności siebie to między innymi budowanie satysfakcjonujących relacji oraz włączenie w społeczeństwo ${ }^{1}$. Pytanie, w jaki sposób udział $\mathrm{w}$ pracy nad spektaklem teatralnym może być dla aktorów z niepełnosprawnością intelektualną - uczestników teatroterapii narzędziem wspomagania poziomu ich pewności siebie, pojawia się w szerokim założeniu od początku koncepcji teatru terapeutycznego. Wpływ tworzenia przedstawienia teatralnego i jego związek z pewnością siebie aktora jest uznawany przez terapeutów z różnych dziedzin nawet za pewnik - regułę teatroterapii. Chociaż nie ma wątpliwości co do zasadności tego związku, to dotąd nie ma badań, które potwierdziłyby związek przyczynowy między oddziaływaniami teatralnymi mającymi na celu promowanie pewności siebie a skutkiem - wzrostem pewności siebie aktorów teatru terapeutycznego², którego doświadczają poza sceną, w życiu codziennym. Nawet wstępna analiza tej zależności warta jest więc podjęcia. Tym bardziej że obecnie coraz częściej obserwuje się, jak „osoby niepełnosprawne starają się być aktywne"3. Pewność siebie wpływająca na zachowanie jednostki może wówczas odgrywać znaczącą rolę.

Istnieją wieloaspektowe zależności zewnętrznych oznak pewności siebie, które zdecydowanie wpływają na percepcję siebie i własnego zachowania. Jako przykład warto wskazać pejoratywne opinie innych, czy utrwalone w pamięci porażki. Z kolei, zdobycie pewności siebie przekłada się na osiągnięcia $\mathrm{w}$ różnych sferach działania, jak na przykład podejmowania samodzielnych decyzji. Albert Bandura w pracy Self-Efficacy: The Exercise of Control wyjaśnił, że pewność siebie (zaufanie do siebie), bardziej niż jakakolwiek inna cecha, przyczynia się do pozytywnych wyników w dążeniu do celu4 Natomiast, brak pewności siebie może wskazywać na brak wiary we własne zdolności, łącznie z brakiem doświadczeń efektywności swoich czynów. Uzyskanie naturalnej, autentycznej pewności siebie to ,jedno z najważniejszych zadań w rozwoju osobistym" ${ }^{5}$. Wiąże się z obrazem własnej osoby, $\mathrm{z}$ wiarą we własne siły, umiejętności, talenty, rozpoznaniem oraz akceptacją swoich możliwości i wad, jak też podejmowaniem działania pomimo swoich ograniczeń. Objawia się ona na przykład śmiałością do wyrażania swojego zdania, nieuleganiem nadmiernie wpływom innych, doświadczaniem zaufa-

\footnotetext{
${ }_{1}^{1}$ T. Stickley, B. Crosbie, A. Hui, The Stage Life: Promoting the Inclusion of Young People Through Participatory Arts, British Journal of Learning Disabilities, 2012, 40, s. 251-258.

${ }^{2}$ Używam zamiennie pojęć teatroterapia i teatr terapeutyczny jako pojęć równoznacznych.

${ }^{3}$ P. Borowiecki, Samoocena osób z niepetnosprawnościa $w$ świetle wybranej literatury i badań własnych, file:// /C:/Users/Anita/Downloads/05-Pawel_Borowiecki\%20(1).pdf, s.110 [dostęp: 03.02.2020].

${ }^{4}$ A. Bandura, Self-Efficacy: The Exercise of Control, New York 1997.

${ }^{5}$ M. Pasterski, Pewność siebie i poczucie własnej wartości, https://michalpasterski.pl/listy/ pewnosc-siebie-i-poczucie-wlasnej-wartosci/ ?read-list=1\&post=6964 [dostęp: 05.02.2020].
} 
nia do własnych cech i ocen. Pewność siebie bezpośrednio wiąże się z osobowością, z poczuciem własnej wartości, a źródła tego poczucia znajdują się w czynnikach zewnętrznych oraz wewnętrznych, stanowiąc integralną część indywidualnej wizji własnej osoby. Wadliwe, nieadekwatne poczucie pewności siebie może skutkować natomiast negatywnie w odniesieniu do opcjonalnej regulacji i funkcjonowania jednostki. Pewność siebie w teatrze terapeutycznym, podobnie jak pewność siebie, nie oznacza poczucia własnej wartości. Wiele razy te dwa pojęcia bywają mylone lub używane zamiennie. Pewność siebie polega na wierze w zdolność do zrobienia czegoś. Poczucie własnej wartości to raczej uczucie lub osąd o sobie. Poczucie własnej wartości ma związek z samooceną człowieka i może mieć wpływ na jego pewność siebie, ale zasadniczo te dwa doświadczenia pozostają odrębne. Teatr terapeutyczny stanowi miejsce, gdzie rodzi się wzajemne wsparcie i poczucie bezpieczeństwa, zrozumienie dla różnych relacji podmiotów skupionych nad konkretnymi sytuacjami teatralnymi, co może wpłynąć na ogólną pewność siebie. Poprzez pewność siebie $\mathbf{w}$ teatrze terapeutycznym rozumiem stan odczuwania przez aktora/uczestnika zdolności do podejmowania zadań teatralnych wraz z przekonaniem o możliwości osiągania wyznaczonych celów artystycznych w obliczu wymagań powstających w toku rozwijania się akcji scenicznej. Jej adekwatny poziom w proporcjonalny sposób odnosi się do ograniczeń oraz możliwości uczestnika i zależy od wielu czynników, których świadomość powinni uzyskać grający. Zadanie terapeuty polega na znalezieniu/wskazaniu powodów, dla których aktor, w tym przypadku teatru terapeutycznego, ma poczuć się bardziej śmiałym i zdecydowanym podczas gry. Z pewnością, nie przebudowuje on sztywnej i niepodatnej na zmiany u osób z niepełnosprawnością samooceny. Jednak proponując określone działania twórcze ukierunkowane na cel terapeutyczny, może przyczynić się także do zwiększenia zaufania do tego, co i jak aktor umie wykonać na scenie nie kierowany z zewnątrz. Wzrost świadomości bycia przygotowanym do gry zwiększa u aktorów - w tym przypadku osób z niepełnosprawnościami teatralną pewność siebie. Zjawisko to przejawia się w postaci zmiany jakości zachowania, teraz zdecydowanego, swobodnego i spontanicznego w podejmowaniu działań twórczych.

\section{Część 1 \\ Kreatywność fundamentem teatru terapeutycznego}

Według Madeline Andresen-Warren, teatr terapeutyczny jest modelem dramaterapii, skupiającym się na procesie uzdrawiania jednostek w grupie teatralnej, na różnych komponentach procesu teatralnego oraz na relacjach 
pomiędzy wykonawcami a widzami. Poprzez tworzenie aktorzy z niepełnosprawnością intelektualną uzyskują pomoc $\mathrm{w}$ rozwijaniu poczucia własnej wartości, pewności siebie oraz wsparcia wspólnoty ${ }^{6}$.

Teatralna pewność siebie stanowi niezwykle ważny aspekt pracy $\mathrm{w}$ teatrze. Dzięki niej, doświadczając poczucia bycia kimś ważnym dla publiczności i partnerów scenicznych, aktor potrafi zaufać wszelkim działaniom, które składają się na proces gry na scenie. Równocześnie może rozwinąć swoje ambicje w kierunku odniesienia sukcesu. W przestrzeni procesu gry i dramatycznej interakcji główną intencją jest dokonywanie odkryć na poziomie ja - aktor, ja - świadek poszukiwań innych, ja - formowany dzięki relacji z widzami, ja - dzięki sobie. Jednakowoż, trzeba podkreślić, jak trudny i długotrwały może być ten swoisty proces dojrzewania, kiedy aktorzy angażują się w tekst $\mathrm{w}$ roli i wchodzą $\mathrm{w}$ interakcję poza rolą. W sytuacji, w której wielu aktorów na co dzień doznaje społecznej i emocjonalnej samotności skutecznie oddzielającej ich od nowych kontaktów interpersonalnych, często mają problemy z połączeniem się ze światem wokół nich i zrozumieniem środowiska społecznego. Doświadczenie teatralne $\mathrm{z}$ definicji połączone z pewną liczbą różnych ról, które aktor - tutaj osoba z niepełnosprawnością - może przyjąć, stanowi doskonałą okazję do podejmowania nowych działań, prób nowych zachowań; szczególnie kuszących o tyle, że świat umowny (scena) nie ma ograniczeń i wybraną rolę można bez przymusu, bez pośpiechu, bezpiecznie wypróbować. $Z$ tego powodu wspomaganie wykonawcy w osiąganiu możliwej swobody łączy się z przyrostem umiejętności relacyjnych zdobywanych dzięki grze i ćwiczeniom roli teatralnej oraz emocji, rozwijanych poprzez stosowanie dramatycznej metafory, które wpływają bezpośrednio na relacje terapeutyczne. To one stanowią dla aktora "osnowę", dzięki której może stać się bardziej świadomy pewnych kwestii i wyzwolić się z wizji człowieka niepełnosprawnego. Dlatego, musi zostać przygotowany przez terapeutę do wyrażania swych myśli, emocji i przeżyć za pomocą języka teatru, w obecności innych członków grupy, w środowisku stworzonym dla sztuki. W celu terapeutycznym zasadność łączenia przestrzeni scenicznej z terapeutyczną dobrze służy doprowadzaniu do zmiany perspektywy, czy też poruszania się w innej perspektywie dotyczącej tej samej sytuacji, na przykład odkrywaniu przyczyn braku pewności siebie $^{7}$. Istotne $\mathrm{w}$ tym procesie jest, że terapeutycznie uwarunkowana eksploracja sceny odnosi się do kreatywnych mediów: teatralnej ekspresji, spontanicznej improwizacji, pogłębiania doświadczeń artystycznych, poprzez które wspomaga się aktora w tworzeniu przeciwwagi do tych ról, które przytłacza-

\footnotetext{
${ }^{6}$ M. Andresen-Warren, "Therapeutic theatre", [w:] Dramatherapy: Clinical Studies, red. S. Mitchell, London 1996.

${ }^{7}$ Zob. R. Emunah, Five progressive phases in dramatherapy and their implications for brief dramatherapy, [w:] Dramatic approaches to brief therapy, red. A. Gersie, London 1996, s. 29-44.
} 
ją go albo wydają się zatrzymywać w rozwoju. Taką dla wielu dorosłych ludzi z niepełnosprawnością jest stygmatyzująca, etykietująca rola osoby niepełnosprawnej o niskiej społecznej akceptacji. Nadal postrzega się dorosłe osoby z niepełnosprawnością intelektualną przez pryzmat ograniczeń, miernych sukcesów życiowych i zawodowych, skali bezradności i koniecznej pomocy. Stąd ważność zwracania uwagi w teatrze terapeutycznym na doświadczenia $\mathrm{w}$ zakresie podejmowania teatralnej roli i znaczenia, jakie odgrywa ona w zwiększaniu skuteczności terapii. Jednakże, terapeuci oferując aktywnie zaangażowanym uczestnikom kontrolę i wybór w budowaniu spektaklu, stwarzają im możliwość promocji własnych pomysłów, samoidentyfikacji osobistych potencjałów. Znawca kreatywności Edward De Bono stwierdził, że polega ona na robieniu "czegoś, co wcześniej nie istniało" ${ }^{8}$ a poprzez tę pojęciową propozycję niejako zapraszał do twórczego działania osoby z niepełnosprawnością intelektualną. Uznając, że kreatywność tych osób, aktorów zaangażowanych $\mathrm{w}$ proces twórczy może być najsilniejszym predykatorem pewności siebie, należy zaznaczyć, jak determinuje ją również doświadczanie wolności twórczej ekspresji jako napędu energii do działania. Według Susan Harter, relacja tego rodzaju może przejawiać się w dwojaki sposób: po pierwsze, ludzie o większej pewności siebie będą łatwiej umieć wyrazić swój potencjał twórczy, aniżeli ci mniej pewni siebie. Po drugie, osoby potrafiące swobodniej korzystać ze swoich zdolności twórczych będą miały tendencję do tego, by stać się bardziej pewnymi siebie, z większym poczuciem bezpieczeństwa9. Teatr terapeutyczny stwarza aktorom wiele szans i okazji zwiększania kreatywności, spontaniczności i zadowolenia ze zdobytych umiejętności rozpoznawanych na poziomie kinestetycznym/zmysłowym, percepcyjnym/ afektywnym, czy poznawczym/symbolicznym, pozwalających zaprezentować się w inny sposób odbiorcy wewnętrznemu lub widzowi. Występ przed zewnętrzną publicznością może, jak pisze Stepphen Snow, potwierdzić te nowe obrazy siebie, które zostały wzmocnione w granej sztuce ${ }^{10}$. Zazwyczaj, kiedy aktor zaczyna zastanawiać się nad tym, co zrobił dobrze, jakie samopoczucie temu towarzyszyło i w jaki sposób następnym razem chciałby jeszcze bardziej coś poprawić, sugeruje, iż ocenia pozytywnie swoje możliwości czy zdolności i spodziewa się pozytywnych skutków swych realizacji. W kontekście budowania teatralnej pewności siebie należy zaobserwować wartość procesu prób teatralnych jako miejsca i czasu budowania „pozycji towarzyskiej”.

${ }^{8}$ E. de Bono, Serious Creativity: Using the Power of Lateral Thinking to Create New Ideas, Harper Business, 1993.

9 S. Harter, Visions of self: Beyond the me in the mirror, [w:] Current theory and research in motivation, vol. 40, red. J.E. Jacobs, Nebraska Symposium on Motivation, 1992: Developmental perspectives on motivation, Nebraska 1993, s. 99-144.

${ }^{10}$ S. Snow, M. D'Amico, D. Tanguay, Therapeutic theatre and well-being, The Arts in Psychotherapy, 2003, 30(2), s. 73-82. 
Jednakże, to występ na scenie jako szczególnie wciągająca forma aktywności może być szczególnie skutecznie wykorzystany w celu zwiększania pewności siebie aktora - człowieka z niepełnosprawnością ${ }^{11}$.

Spektakl teatralny jest efektem pracy zespołu, ale każda osoba zachęcona przez terapeutę może sama zdecydować, w jaki sposób konkretna scena się zakończy lub w jaki sposób dana postać zareaguje na przeszkodę lub otrzymaną pomoc. Tworzenie sztuki jest procesem o charakterze terapeutycznym, stąd w trakcie rozwijania się narracji dramatycznej jest czas wspierania siebie nawzajem, czas na drobne, ale zasłużone osiągnięcia, jak również negocjowanie oraz współpracę, bo aktorzy chcą mieć wpływ na końcowy występ i tutaj to oni są właścicielami sztuki. Jeśli efekt końcowy jest dobry, wszyscy wykonawcy są pewniejsi siebie dzięki silnemu poczuciu sukcesu. Widząc pozytywne rezultaty swojego wysiłku, potrafią przetrwać trudne chwile kryzysu bardziej zmotywowani do kolejnych etapów pracy teatralnej. Jednakże, sukces może stać się również przyczyną nieuzasadnionego wzrostu teatralnej pewności siebie i przyczynić do nieadekwatnego wizerunku własnej osoby. Tym bardziej trzeba więc wspomagać prawidłowe przekonania aktora o swoich realnych umiejętnościach. Warto zaznaczyć, iż teatroterapię wyróżnia nie, jak błędnie się nieraz twierdzi, pomijanie znaczenia efektu estetycznego, artystycznego, ale przekaz emocjonalny, a tym samym wartościowanie oraz radowanie się z zasobów odkrytych na poziomie fizyczności, ruchu i dźwięku tworzących strukturę scen. Także asocjacje dochodzące ze sfery kinestetycznej i symbolicznej rozszerzają percepcyjne zasoby jednostki wychodzące poza słowne (pojęciowe) rozumowanie. Poszerzająca perspektywy przydatność pracy teatralnej dla aktora tego teatru zaczyna się od odwoływania się w codzienności do treści własnych przeżyć doświadczonych w procesie działań scenicznych. Dlatego, efekt w postaci „dobrego" przedstawienia pełni tutaj znaczącą funkcję. Sens wszystkiego leży w działaniu, w doskonaleniu partytury jako wspólnego dzieła i równocześnie narzędzia samoobserwacji. To, co odczuwa aktor jako podmiot sprawczy i to, co $\mathrm{w}$ aktorze i na scenie się zmienia podczas procesu tworzenia jest praktykowaniem teatru, a zaczyna się od osiągnięcia gotowości do przekraczania osobistych ograniczeń. To moment inicjacji pewności siebie, przyczynek zwiększania osobistej i społecznej świadomości. David R. Johnson wyjaśnia, że celem oddziaływań przez grę (dramę) jest

zwiększenie elastyczności osoby w dostosowaniu się do nowych uczuć i sytuacji, osiągniętych poprzez wzmocnienie zdolności do samoobserwacji, kwestionowania

${ }^{11}$ Por. S. Hackett, J. Bourne, The Get Going Group: Dramatherapy with adults who have learning disabilities and mental health difficulties, Dramatherapy, 2014, 36, s. 43-50. 
i tolerowania dwuznaczności (...) pomoc (...) w znalezieniu przebaczenia dla swych ograniczeń i ograniczeń innych ${ }^{12}$.

Wypada podkreślić, że $\mathrm{w}$ teatroterapii zmiana postrzegana jest nie $\mathrm{w}$ sensie korekcyjnym, a raczej transgresyjnym, jako wzmacnianie, motywowanie, czy odnajdywanie zasobów jednostki i tego, czym potrafi się ona dzielić z innymi.

\section{Część 2 \\ Pewność siebie - nowa perspektywa obrazu siebie}

Teatroterapia w podejściu holistycznym oparta jest na możliwościach, do ujawniania których prowadzi gra teatralna i rozszerzanie repertuaru ról. Odkrywanie swoich potencjalności jest szansą, aby prawdziwie umieścić się w wyobrażonym świecie. Można przewidzieć, iż im bardziej ocena swego udziału w budowaniu spektaklu i jego sukcesu zauważonego przez innych jest zbieżna z subiektywną oceną przyrostu własnych możliwości, tym więcej pewności siebie aktora pojawi się w kolejnych etapach pracy nad rolą teatralną. Interesujące jest, jak stan ten motywuje do działania aktorów z niepełnosprawnością intelektualną, łącząc ich osobistą ekspresję z przyrostem dramatycznych i teatralnych umiejętności oraz o ile chętniej dokonują przeglądu czego się nauczyli, ćwicząc nowe zachowania w teatralnych rolach lub eksperymentując z tym, jak zmienić stare zachowania. Zaczynając od zabaw, dzięki którym łatwiej zaoferować uczestnikowi nowe pozytywne alternatywy dla zachowania, by nie pogłębiał niezdrowych nawyków, przez odczucia rozczarowania i złości, aż do doświadczania znaczących wyzwań prowadzi droga wzmacniania jego zdrowej pewności siebie. Badania sugerują, że przekonania, jakie jednostki mają na temat swoich możliwości, silnie wpływają na sposób, w jaki się zachowują i co osiągają ${ }^{13}$. Zaangażowanie się aktora $\mathrm{w}$ grę i nastawienie do grania wpływa bezpośrednio na kierowanie życiem odgrywanej postaci oraz możliwie samodzielne kontrolowanie wykonania (zgodnie z określonym zadaniem aktorskim). Potrzebna jest więc im umiejętność podejmowania decyzji, zwracania się do zespołu o pomoc w jej realizacji, stąd stałe rozmowy toczące się wokół roli, która staje się narzędziem do zrozumienia, monitorowania oraz utrzymywania lub wzmacniania pewności siebie w zakresie konkretnej zdolności. Może dotyczyć odwagi, by wyartykułować to, czego się osobiście pragnie, czy też przekonania do

${ }_{12}$ D.R. Johnson, The theory and technique of transformations in drama therapy, The Arts in Psychotherapy, 1991, 18(4), s. 287.

${ }_{13}$ T. Żółkowska, Poziom samoakceptacji osób z głębsza niepetnosprawnościa, [w:] Człowiek z niepetnosprawnościa intelektualna, tom I - Wybrane problemy osobowości, rodzin i edukacji osób z niepetnosprawnością intelektualna, red. Z. Janiszewska-Nieścioruk, Kraków 2003, s. 50-68. 
jakich posiadanych możliwości oraz ograniczeń aktor może się faktycznie odwoływać, czy wiara we własne siły odpowiada jego rzeczywistym możliwościom. Bycie w kontakcie z rzeczywistością, jak twierdzi Nathaniel Branden, jest pierwszym krokiem do budowania poczucia własnej pewności ${ }^{14} \mathrm{i}$ warto o tym pamiętać, gdyż aktorzy będący podmiotem oddziaływań terapeutycznych skupieni w tym teatrze mają odmienny bagaż doświadczeń. Różnorakie bywają sposoby ich postępowania, rozumienia i oceniania świata. Są one kształtowane w niejednolitych środowiskach rodzinnych, dlatego odmienne bywają oblicza ich pewności siebie.

Działania teatralne jako zdarzenia zarówno nowe, jak i niespodziewane wymagają podawania aktorom kontekstowych wskazówek obecnych w codziennej interakcji. Rozwijanie natomiast jego gotowości do odgrywania ról służące poprawie swych ograniczeń lub ułatwieniu sprawności funkcjonalnych zależy w dużym stopniu od siły pozytywnych emocji płynących z przekonania o swoim znaczeniu $w$ tworzeniu sztuki. Zbyt pewni siebie podczas działań teatralnych szybko podejmują się zadań, których nie są $\mathrm{w}$ stanie $\mathrm{w}$ takim trybie wykonać i kiedy nie radzą sobie $\mathrm{z}$ nimi, nie potrafią zwrócić się wówczas o pomoc, nie umieją wytrwać w scenach, szczególnie z wolniejszymi partnerami. Najczęściej efektem jest zawód, rozżalenie, gniew, co przekłada się na stosunki z grupą i gorszy kontakt podczas scen $\mathrm{z}$ partnerem. Natomiast, proces pracy nad rolą w przypadku uczestników z zaniżoną pewnością siebie wyraźnie obrazuje ich uczucie niepewności, podczas gdy uzależniają się $\mathrm{w}$ centralnych momentach pracy nad rolą od pomysłów osób trzecich i dostosowują się do tego, czego inni od nich oczekują nawet wówczas, kiedy wcześniej doświadczyli radości ze swojej aktywności. Pierwsi często uważają, że są bardziej sympatyczni i atrakcyjni, mają lepsze relacje interpersonalne, $\mathrm{z}$ kolei drudzy podczas budowania roli często wykazują tendencje do tłumienia ekspresji emocji, zakładają z góry, że nie osiągną pożądanego rezultatu, co w dużej części nie koresponduje z ich możliwościami kreacji. Osiąganie pewności siebie jest doświadczeniem proaktywnym i odnosi się do zgodności i trafności samooceny z faktycznymi możliwościami. Natomiast, jej osiąganie u osób z niepełnosprawnością intelektualną warunkują specyficzne trudności, wyzwalające swoiste zachowania powiązane $\mathrm{z}$ utrudnieniami wynikającymi z zaburzeń $w$ rozwoju $w$ sferze percepcyjnej i poznawczej, wynikające z osłabionego krytycyzmu, a także ogromnej chęci sukcesu dostrzeganego przez innych. Utrudnione, w zależności od stopnia niepełnosprawności, jest zbieranie spostrzeżeń i wyobrażeń na swój temat, formujących określoną wiedzę o sobie oraz powstały na

${ }^{14} \mathrm{~N}$. Branden, The art of living consciously: The power of awareness to transform everyday life, New York 1997, s. 171. 
tej bazie proces oceniania siebie ${ }^{15}$, stąd wiele pozytywnych, a nieuzasadnionych stwierdzeń na temat znacznych zdolności i kompetencji. Łączy się to z kwestią wpływu, jaki odgrywa brak akceptacji i strach przed społecznym odrzuceniem, przeżywanie okazywanego dystansu przez innych sprawnych ludzi i wynikającą z tego tęsknotę do zbliżania się do nich. Poza tym

osoba niesprawna intelektualnie zna siebie jedynie - lub głównie - z roli „pod”. Jest kimś słabszym, kim trzeba się opiekować, komu potrzebne jest wsparcie oraz pomoc. Widzi siebie jako osobę zależną. Takie doświadczenia mogą prowadzić do postawy roszczeniowej albo biernej ${ }^{16}$.

Zadanie terapeuty, który nie tylko wspomaga i towarzyszy aktorowi w procesie twórczym (kreacji teatralnej), ale także uczy się często od niego, polega na kwestionowaniu negatywnych wzorców jego myślenia o sobie. Jest to proces długotrwały, wymagający wzajemnej cierpliwości, odbywający się poprzez wprowadzanie w działania artystyczne nowych alternatywnych matryc, przy jednoczesnym traktowaniu życiowych przeżyć aktora jako źródła wiedzy. Wykonawca systematycznie zachęcany do działania ma dużą szansę doświadczania innej percepcji siebie, stąd też bodziec, by zmierzyć się ze swoimi trudnościami, a tego rodzaju doświadczanie może pomagać poznać czynniki, które zwiększają i osłabiają pewność siebie.

Niewątpliwie, $w$ procesie teatroterapii podstawą jest zaangażowanie aktorów w proces twórczy oraz dialog niezbędny dla zrozumienia i prawidłowego reagowania na partnera z pozycji granego bohatera, którego losy często ukazują problem grającego. Również umiejętność identyfikacji i połączenie różnych jakości prezentowanych umiejętności oraz doświadczanie pomyłki. Błąd może być fantastycznie wykorzystany, aby przekierować i poprowadzić grającego do pomysłowej zmiany, do permutacji zdarzeń ożywiającej akcję. Staje się okazją do rozmowy na tematy związane ze wsparciem, radzeniem sobie z problemami i nabierania odporności. D. Heddon i J. Milling wyjaśniają, że tworzenie teatru jest ciągłym procesem poruszania się tam i z powrotem - między strukturą a spontanicznością (między porządkiem a chaosem) w celu umożliwienia, by nowy materiał mógł się rozwinąć i zostać odkryty ${ }^{17}$.

Ryc. 1. Najczęstsze uwarunkowania/źródła pewności siebie w teatroterapii

15 Więcej na ten temat: Z. Janiszewska-Nieścioruk, Znaczenie samooceny w społecznej integracji niepetnosprawnych intelektualnie, Zielona Góra 2000.

${ }_{16}$ L. Bakiera, Ż Stelter, Wspomaganie rozwoju osób niepetnosprawnych intelektualnie, [w:] Potrzeby i modele pomocy dla osób z ograniczeniami sprawności, red. A. Brzezińska, R. Kaczan, K. Smoczyńska, Warszawa 2010, s. 148.

17 D. Heddon, J. Milling, Devising performance: A critical history, New York 2006; zob. M. Franklin, Art Therapy and Self-Esteem, Journal of the American Art Therapy Association, 2013, s. 78-84. 


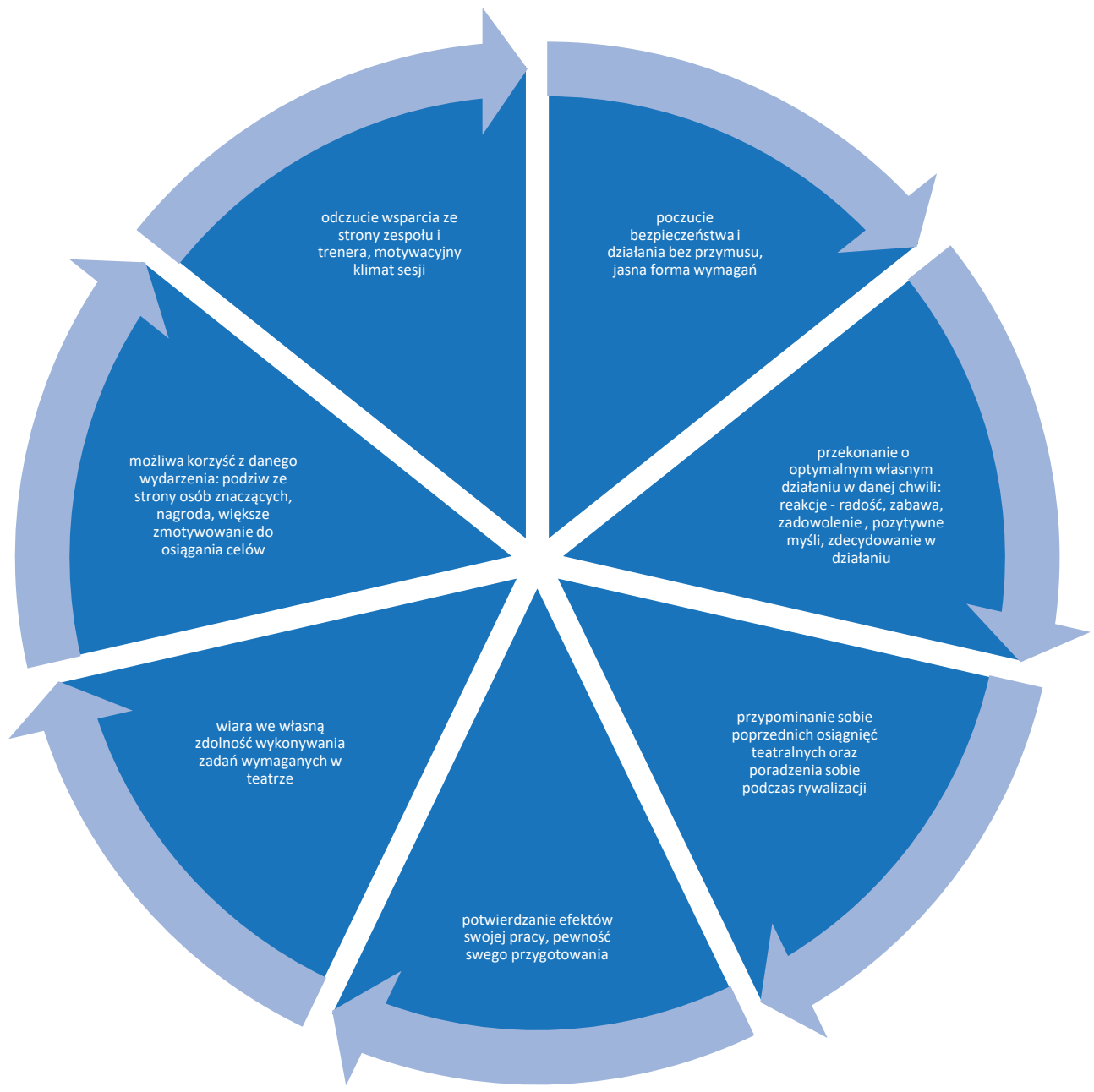

(źródło: opracowanie własne)

Zgodnie z założeniem wyjściowym w oddziaływaniu teatroterapeutycznym, sytuacje odgrywane na scenie są tak podobne do życiowych, jakby były tożsame. Tożsamość dotyczy jednak zawsze i wyłącznie sfery opisu, złożonej nazwy, nie treści przeżycia. Dzielenie i zagospodarowanie tej samej przestrzeni dla wspólnego tworzenia umożliwiają procesy transformacyjne, podtrzymywane przez wzajemne interakcje, takie jak wspieranie wzajemnego uznania, przestrzeganie zasad panujących w zespole, czy ich regulacji. Prawdopodobnie, to również możliwości zaistnienia $\mathrm{w}$ grupie w równoprawnej roli budują większą pewność siebie, ponieważ rodzi to u aktorów przekonanie o swojej ważnej pozycji w zespole, a wyraźna akceptacja grupy, kom- 
plementy słyszane od osób z zewnątrz grupy pozwalają potwierdzać wiarę i zaufanie we własne siły. Ostatecznie, także i zdolności do pokonywania przeszkód wzmacniają odczuwanie ważności swojej osoby. Aktorzy z niepełnosprawnością intelektualną mają zrozumienie dla podobnych trudności na scenie, podobnie szukają uznania za swoje wysiłki, ale ich wiara we własne możliwości niestety często nadmiernie wzrasta, ponieważ stawiają sobie cele, które są zbyt trudne do osiągnięcia ${ }^{18}$.

\section{Zakończenie}

Teatr to sztuka, która obejmuje całą osobę w sposób aktywny. Tylko dzięki właściwemu postrzeganiu swoich zalet oraz pozytywnemu nastawieniu stopniowo zmienia się sposób, w jaki aktor wchodzi w przestrzeń sceniczną, zmienia się poziom zaufania do tego co potrafi zrobić i zagrać. Zmienia się świadomość ciała i zachowań niewerbalnych w przestrzeni kontaktu. Znaczenia nabierają taktyki, które promuje się pozytywnie w relacjach interpersonalnych: formy mimiczne, niewerbalne wokalizowania (śmiech, chichot), dotyk czy gesty, które ubarwiały i cennie dookreślały graną przez siebie postać. Sceny rodzą się z dialogu lub z/w ciszy, bezpośrednio dostosowując sceniczne dzianie się do umiejętności grupy, która wspólnie próbuje odnaleźć odpowiednią postawę wobec sytuacji problemowej, wobec nowych i niecodziennych dla niej wyzwań. Tymczasem, nigdy nie wiadomo co stanie się na scenie, kiedy gromadząc całą swoją odwagę, aktor chce się czegoś nauczyć. Wielu znanych mi teatroterapeutów, na koniec spotkań warsztatowych domykających cykl pracy, podczas procedury wyjścia zadaje to samo pytanie uczestnikom: Czy uważasz, że bycie artysta zmieniło cię? Uczyniło cię innym? Odpowiedzi odzwierciedlających zwiększoną kreatywność jest porównywalnie tyle, co odpowiedzi odzwierciedlających zwiększone zadowolenie; więcej jest odpowiedzi odzwierciedlających zwiększoną pozytywną samoocenę oraz odpowiedzi wskazujących na ambicje dotyczące rodziny oraz związków partnerskich, ale najbardziej widoczne i zapamiętane są przez wszystkich reakcje odzwierciedlające zwiększoną pewność siebie i wiarę dorosłego człowieka w swoje możliwości życiowe. Doświadczanie pewności siebie jest ważnym obrazem tego, jak dobrze sobie radzimy, a ten stan przenika myśli, uczucia i nasze działania.

Wiara w siebie to nie kwestia przypadku. Należy ją pielegnować i uzupetniać, kiedy się obniża, a stopować, kiedy zbytnio lub nachalnie rośnie. Stan ten ulega zmianom, jednak doświadczenie wzrostu zaufania do siebie związane

${ }^{18}$ Por. S. Hackett, J. Bourne, The Get Going Group: Dramatherapy with adults who have learning disabilities and mental health difficulties, Dramatherapy, 2014, 36, s. 43-50. 
z pracą nad spektaklem w teatrze terapeutycznym może stworzyć dorosłym ludziom z niepełnosprawnością intelektualną okazję i możliwość zmierzenia się ze swoją nieproduktywnie zawyżoną albo zbytnio obniżoną pewnością.

\section{BIBLIOGRAFIA}

Andresen-Warren M., "Therapeutic theatre", [w:] Dramatherapy: Clinical Studies, red. S. Mitchell, Jessica Kingsley, London 1996.

Bakiera L., Stelter Ż., Wspomaganie rozwoju osób niepetnosprawnych intelektualnie, [w:] Potrzeby i modele pomocy dla osób z ograniczeniami sprawności, red. A. Brzezińska, R. Kaczan, K. Smoczyńska, Wydawnictwo Naukowe Scholar, Warszawa 2010.

Bandura A., Self-Efficacy: The Exercise of Control, Worth Publishers, New York 1997.

Baumgardner A.H., To know oneself is to like oneself. Self-certainty and self-affect, Journal of Personality and Social Psychology, 1990, 58.

Bono de E., Serious Creativity: Using the Power of Lateral Thinking to Create New Ideas, Harper Business, 1993.

Borowiecki P., Samoocena osób z niepetnosprawnością w świetle wybranej literatury i badań własnych, file://C:/Users/Anita/Downloads/05-Pawel_Borowiecki\%20(1).pdf, s.110 [dostęp: 03.02.2020].

Branden N., The art of living consciously: The power of awareness to transform everyday life, Simon i Schuster, New York 1997.

Emunah R., Five progressive phases in dramatherapy and their implications for brief dramatherapy, [w:] Dramatic approaches to brief therapy, red. A. Gersie, Jessica Kingsley, London 1996.

Franklin M., Art Therapy and Self-Esteem, Journal of the American Art Therapy Association, 2013.

Hackett S., Bourne J., The Get Going Group: Dramatherapy with adults who have learning disabilities and mental health difficulties, Dramatherapy, 2014, 36.

Harter S., Visions of self: Beyond the me in the mirror, [w:] Current theory and research in motivation, vol. 40, red. J.E. Jacobs, Nebraska Symposium on Motivation, 1992: Developmental perspectives on motivation, University of Nebraska Press 1993.

Heddon D., Milling J., Devising performance: A critical history, Palgrave, New York 2006.

Janiszewska-Nieścioruk Z., Znaczenie samooceny w społecznej integracji niepetnosprawnych intelektualnie, Lubuskie Towarzystwo Naukowe, Zielona Góra 2000.

Johnson D.R., The theory and technique of transformations in drama therapy, The Arts in Psychotherapy, 1991, 18(4).

Pasterski M., Pewność siebie i poczucie własnej wartości, https://michalpasterski.pl/listy/pewnosc-siebie-i-poczucie-wlasnej-wartosci/?read-list=1\&post=6964 [dostęp: 05.02.2020].

Snow S., D'Amico M., Tanguay D., Therapeutic theatre and well-being, The Arts in Psychotherapy, 2003, 30(2).

Stickley T., Crosbie B., Hui A., The Stage Life: Promoting the Inclusion of Young People Through Participatory Arts, British Journal of Learning Disabilities, 2012, 40.

Żółkowska T., Poziom samoakceptacji osób z głębsza niepetnosprawnościa, [w:] Człowiek z niepetnosprawnościa intelektualna, tom I - Wybrane problemy osobowości, rodzin i edukacji osób z niepetnosprawnościa intelektualna, red. Z. Janiszewska-Nieścioruk, Oficyna Wydawnicza Impuls, Kraków 2003. 